\title{
Analisis Kinerja TCP/IP untuk Jaringan Nirkabel Bergerak 3G di Surabaya
}

\author{
Nurul Hidayati dan Suwadi \\ Jurusan Teknik Elektro, Fakultas Teknologi Industri, Institut Teknologi Sepuluh Nopember (ITS) \\ Jl. Arief Rahman Hakim, Surabaya 60111 Indonesia \\ e-mail:nurul14@mhs.ee.its.ac.id, suwadi@ee.its.ac.id
}

\begin{abstract}
Abstrak- Surabaya akan menerapkan Intelligent Transport System (ITS), yaitu sistem transportasi yang cerdas, di mana komunikasi data menjadi poin utama karena ITS berbasis pada internet. ITS menggunakan protokol TCP/IP. TCP mengoptimalkan pengiriman data yang akurat daripada ketepatan waktu. Sehingga terkadang menimbulkan keterlambatan yang panjang karena data akan ditransmisikan ulang atau menunggu pesan out-of-order. Keterlambatan transmisi data ini harus ditekan seminim mungkin agar kontinuitas pengiriman data tetap terjaga dengan baik. Analisis dibutuhkan untuk mengetahui seberapa lama keterlambatan dalam transmisi data dari provider seluler 3G. Pengukuran diambil dari beberapa provider seluler, sehingga dapat dibandingkan performansi dari masing-masing provider. Parameter yang dianalisis yaitu delay. Pengukuran dilakukan di dalam kendaraan bergerak (kereta api komuter) selama 7 hari, dengan setiap harinya terdapat 4 kali jadwal pemberangkatan. Dari hasil pengukuran pada 4 provider, didapatkan bahwa saat delay kurang dari 5000 ms nilai CDF pada provider A sebesar $75 \%$, provider $\mathrm{B}$ dengan nilai CDF $81 \%$, provider $\mathrm{C}$ dengan nilai CDF 90\% dan provider D dengan nilai CDF 77\%. Dari keempat provider, nilai CDF yang paling tinggi adalah provider $C$ sebesar $\mathbf{9 0 \%}$. Sehingga dapat digunakan sebagai pertimbangan sistem komunikasi nirkabel bergerak pada penerapan Intelligent Transport System (ITS) untuk aplikasi mengetahui posisi kendaraan pada angkutan masal cepat, karena nilai delay toleransi sebesar 5 detik.
\end{abstract}

Kata Kunci-3G, bergerak, TCP/IP, delay, ITS, kereta api

\section{PENDAHULUAN}

SURABAYA akan menerapkan Intelligent Transport System (ITS), yaitu sistem transportasi yang cerdas, di mana komunikasi data menjadi poin utama karena ITS berbasis pada internet. Sehingga keterlambatan transmisi data harus ditekan seminim mungkin agar kontinuitas pengiriman data ke server tetap terjaga dengan baik. Dibutuhkan provider yang konsisten dalam melayani pengiriman data. Salah satu aplikasi pada ITS adalah mengetahui lokasi kendaraan, dengan mengirim informasi titik latittude dan longitude dari gps di kendaraan ke server. ITS menggunakan protokol TCP. TCP mengoptimalkan pengiriman data yang akurat daripada ketepatan waktu. Sehingga terkadang menimbulkan keterlambatan yang panjang. Karena data akan ditransmisikan ulang atau menunggu pesan out-of-order. Analisis dibutuhkan untuk mengetahui seberapa lama keterlambatan dalam transmisi data dari provider seluler 3G. Menurut survey yang dilakukan oleh "Deloitte Global Mobile Consumer Survey" terhadap penggunaan jaringan $3 \mathrm{G}$ dan $4 \mathrm{G}$ di beberapa negara
ASEAN (Desember 2015), 73\% penduduk di Indonesia menggunakan jaringan 3G[15].

Untuk itu penelitian ini bertujuan untuk mengukur dan menganalisis kinerja TCP/IP pada jaringan nirkabel bergerak 3G, dalam hal ini delay. Sehingga dapat mendukung serta menjadi pertimbangan sistem komunikasi nirkabek bergerak pada penerapan Intelligent Transport System (ITS) di Surabaya.

\section{TINJAUAN PUSTAKA}

\section{A. Intelligent Tranport System (ITS)}

Intelligent Tranport System (ITS) adalah sistem transportasi pintar yang menggunakan kecerdasan buatan (Artificial Intelligence) meliputi teknologi, analisa sistem, analisa kebutuhan, manajemen transportasi daerah dan insfrastruktur [4]. ITS berguna untuk tercipta sistem transportasi yang lebih aman, nyaman dan mudah digunakan. Tujuannya untuk pengelolaan transportasi yang baik, berbasiskan komputer dan internet.Selain itu ITS memiliki kemampuan sebagai berikut :

1. Kemampuan untuk mengetahui ada tidaknya kendaraan yang lalu lalang di jalan raya, dengan adanya teknologi GPS (Global Positioning Systems).

2. Kemampuan untuk melakukan komunikasi antar komputer melalui jaringan internet.

3. Kemampuan untuk menyajikaan data yang telah diolah menjadi informasi yang bermanfaat ke sistem.

Konsep Intelligent Tranport System (ITS) mulai diterapkan di Indonesia, terlebih di Surabaya. Pertumbuhan penduduk yang semakin meningkat drastis, membuat tingginya angka kemacetan dan kecelakaan. Sehingga dibutuhkan konsep ITS dalam memanfaatkan teknologi Komunikasi Informasi dalam mendukung manajemen transportasi di Surabaya. Terdapat 3 macam prioritas layanan ITS di Surabaya, yaitu :

a. Layanan Manajemen Lalu-Lintas (Traffic Management System): meliputi kendali real-time, informasi lalu lintas, pengawasan visual, pengawasan dan kendali lintasan manual dan interkoneksi Dishub - polisi lalu lintas.

b. Manajemen Informasi Traffic : pengolahan data traffic meliputi informasi lalu lintas, informasi traffic, informasi rute alternatif, SMS server, informasi parkir umum dan kondisi lalu linntas jalan.

c. Pemanfaatan ITS pada transportasi massal : menyajikan informasi angkutan masal dan manajemen kendaraan umum.

Penerapan ITS sudah dilakukan untuk alat pengendali isyarat lalu lintas, dengan sistem Adaptive Traffic Control System (ATCS). Sistem ini dapat mengatur waktu nyala lampu lalu lintas secara real-time, berdasarkan kondisi kepadatan 
kendaraan saat itu.

Pada Gambar 1 disajikan bahwa Angkutan Massal Cepat (AMC) juga akan diterapkan di Kota Surabaya. Pada AMC Surabaya ini, ada beberapa moda transportasi yang digunakan seperti angkot, bus, tram dan monorail. Untuk tram menghubungkan jalur Surabaya utara sampai Surabaya selatan (JMP - Joyoboyo) dengan jarak $\pm 16,7 \mathrm{~km}$. Sedangkan untuk monorail menghubungkan Surabaya timur sampai Surabaya barat (Lidah Kulon - Kejawan) dengan jarak lebih jauh \pm 23 $\mathrm{km}[5]$.

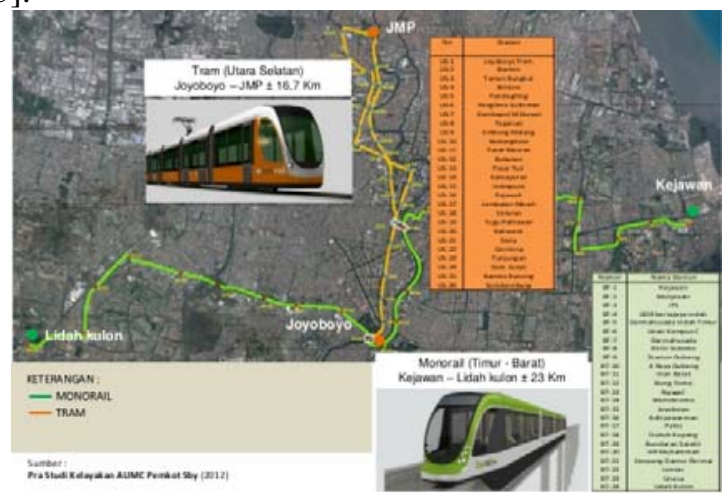

Gambar 1. Angkutan Massal Cepat Trem dan Monorail di Surabaya[5]

Untuk aplikasi lain yaitu mengetahui posisi kendaraan dalam hal ini angkutan cepat masal, yang dilengkapi dengan GPS pada OBU kendaraan. Client akan mengirim longitute dan latitude ke server. Sehingga server dapat memberi pesan kondisi kendaraan yang lain, agar tidak terjadi penumpukan kendaraan. Untuk batas minimal delay yang dapat ditoleransi yaitu ketika delay $5 \mathrm{~s}$ untuk kendaraan bergerak [6].

\section{B. Model TCP/IP}

TCP/IP merupakan standar komunikasi data yang digunakan dalam proses tukar-menukar data dari satu komputer ke komputer lain. TCP/IP merupakan jaringan terbuka yang bersifat independen terhadap mekanisme transport pada jaringan fisik yang digunakan, sehingga dapat digunakan di mana saja. Protokol ini menggunakan skema pengalamatan yang sederhana yang disebut sebagai alamat IP (IP Address) yang mengizinkan banyak komputer untuk dapat saling berhubungan satu sama lainnya di Internet. Protokol ini juga bersifat routable yang berarti protokol ini cocok untuk menghubungkan sistem-sistem berbeda untuk membentuk jaringan yang heterogen[10]. Pada model TCP/IP terdapat empat lapisan yang memiliki fungsionalitas masing-masing, yaitu : Physical Layer, Network Access, Internet Layer, Transport Layer, Application Layer.

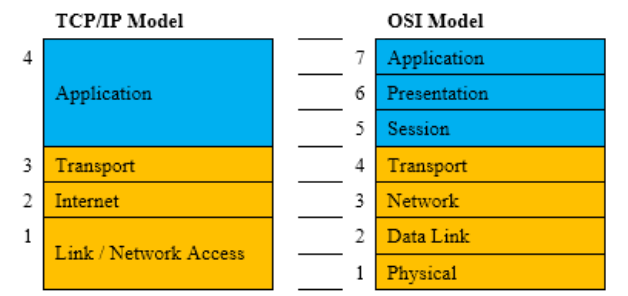

Gambar 2. Model TCP/IP dibandingkan dengan model OSI [4]

\section{C. $3 G$ (Third Generation)}

UMTS yang biasa dikenal sebagai teknologi 3G hadir untuk meneruskan kesuksesan teknologi sebelumnya (2G) yang biasa disebut GSM dan evolusi dari General Packet Radio Service (GPRS). UMTS berbeda didalam penggunaan air interface yang berbasis pada Wideband Code Division Multiple Access (WCDMA) yang mana pada 2G GSM dan GPRS menggunakan Time Division Multile Access (TDMA). Di bawah ini merupakan arsitektur UTMS.

\section{Delay}

Delay didefinisikan sebagai waktu tunda suatu paket yang diakibatkaan oleh proses transmisi dari tempat pengirim ke server kembali lagi ke tempat pengirim. Terdapat beberapa faktor-faktor yang mempengaruhi delay pada jaringan nirkabel bergerak antara lain :

a. Jaringan

Jaringan dengan trafik yang tinggi, apabila banyak pengguna jaringan yang melakukan koneksi ke server di dalam jaringan itu, sehingga lalu lintas paket data pada jaringan menjadi padat menyebabkan terjadi antrian dalam jaringan [6]. Hal ini dapat menimbulkan delay.

b. Mobilitas

Saat terjadi perpindahan lokasi dari satu titik ke titik lain akan menyebabkan handover. Waktu tunggu saat peralihan dari sel BTS satu ke sel BTS lain dapat menyebabkan delay.

c. Pengguna jaringan

Semakin banyak pengguna jaringan beban trafik pada jaringan akan semakin meningkat (overload traffict), hal ini dapat mengakibatkan penuhnya kapasitas jaringan sahingga menyebabkan antrian.

d. Waktu Pengukuran

Apabila dilakukan pengukuran pada jam-jam sibuk, pengguna jaringan semakin banyak. Ini menyebabkan trafik menjadi padat.

\section{e. Dropped Packets}

Router akan membuang paket (drop) jika terdapat paket yang rusak atau paket tersebut sampai pada saat buffer router penuh. Ini menyebabkan pengiriman ulang terhadap paket tersebut, ini dapat menyebabkan terjadinya delay pada aliran transmisi tersebut [11].

Acuan delay yang digunakan pada tugas akhir ini merupakan standar dari SLAC (Stanford Linear Accelerator Center)[12]. SLAC adalah pusat penelitian Universitas Stanford yang dilakukan oleh Departemen Penelitian Energi Nasional. Penelitiannya berkaitan dengan telekomunikasi, salah satunya tentang kualitas kinerja jaringan (QoS), dalam hal ini delay. Pada Tabel 1 dipaparkan standar delay menurut SLAC.

\begin{tabular}{rll}
\multicolumn{2}{c}{ Tabel 1.Standar nilai delay dari kecepatan mendapat jawaban menurut SLAC } \\
\hline \hline Range delay (s) & Penggolonggan & Keterangan \\
\hline $0-0,4$ & High productivity & Baik sekali, sangat \\
$0,4-2$ & Fulteractive response & interaktif \\
$2-12$ & Sporadically interactive & Baik, semua terlayani \\
& regime & Sedang, hampir semua \\
& terlayani \\
$>12$ & Break in contact regime & Buruk, pemutusan \\
& & koneksi \\
\hline
\end{tabular}




\section{E. Fungsi Distribusi Komulatif (CDF)}

Fungsi distibusi komulatif atau Cummulative Distribution Function (CDF) menyatakan jumlahan dari seluruh nilai fungsi probabilitas yang lebih kecil atau sama dengan nilai yang ditetapkan[13]. CDF menjumlahkan tiap nilai PDF dari setiap range. Fungsi distribusi kumulatif dituliskan dalam bentuk persamaan 2.2

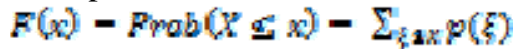

Jadi fungsi distribusi kumulatif $\mathrm{F}(\mathrm{x})$ adalah jumlah dari seluruh nilai probabilitas untuk nilai X sama atau kurang dari $\mathrm{x}$.

\section{METODE PENGUKURAN}

Pada tugas akhir ini dilakukan pengukuran delay pada jaringan 3G karena teknologi 3G masih mendominasi di Indonesia. Terbukti dengan survei pada bulan Desember 2015 yang dilakukan oleh lembaga survei Deloitte Global Mobile Consumer, 73\% penduduk Indonesia menggunakan jaringan 3G. Selain itu pengukuran delay ini dilakukan pada kendaraan bergerak, yaitu kereta api komuter. Karena akan digunakan pada angkutan massal ITS di Surabaya. Salah satunya aplikasi mengetahui lokasi kendaraan. Setiap angkutan massal akan mengirimkan informasi titik latittude dan longitude dari gps di kendaraan ke server. Ini berfungsi untuk mengantisispasi kemacetan dan mengetahui posisi kendaraan ketika terjadi kecelakaan.

\section{A. Metode Pengerjaan Tugas Akhir}

Pada Gambar 2. ditampilkan diagram tulang ikan untuk metode pengerjaan tugas akhir.

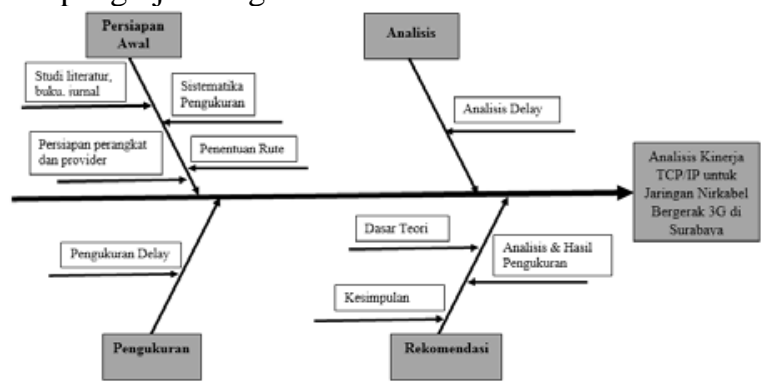

Gambar 3. Metode pengerjaan tugas akhir

\section{B. Kebutuhan Perangkat Penunjang}

Sebelum melakukan pengukuran, dibutuhkan perangkat keras dan perangkat lunak sebagai penunjang, yaitu :

1) Kebutuhan Perangkat Lunak

Perangkat lunak yang dibutuhkan yaitu :

a) Aplikasi PNetDlyTestV2016

b) Wireshark

c) GPSLogger

d) Vmware

e) XAMPP

2) Kebutuhan Perangkat Keras

Perangkat keras yang dibutuhkan yaitu :

a) Dua buah laptop dengan spesifikasi :

1) Processor : AMD A8 4500M

2) Speed $: 1.9 \mathrm{GHz}$ Cache $4 \mathrm{MB}$

3) Memori : DDR3 2GB

4) Storage : Harddisk SSD

5) Interkoneksi : wifi 802.11bgn dan bluetooth b) 2 buah Mobilephone

c) 2 buah Modem

\section{Arsitektur Pengukuran Delay}

Pada Gambar 5 merupakan arsitektur pengukuran menggunakan jaringan 3G. Pengukuran menggunakan dua buah laptop, masing-masing laptop dikoneksikan dengan modem dan mobile phone melalui teathering. Kemudian laptop akan mengirim data ke server, dan server akan memberi balasan ke laptop kembali. Sehingga didapat delay yang dimaksud. Setiap 15 detik laptop akan mengirim data, waktu sudah dibuat otomatis pada aplikasi pengukurannya. Dan pada Gambar 6 disajikan konfigurasi alat untuk pengukuran delay.

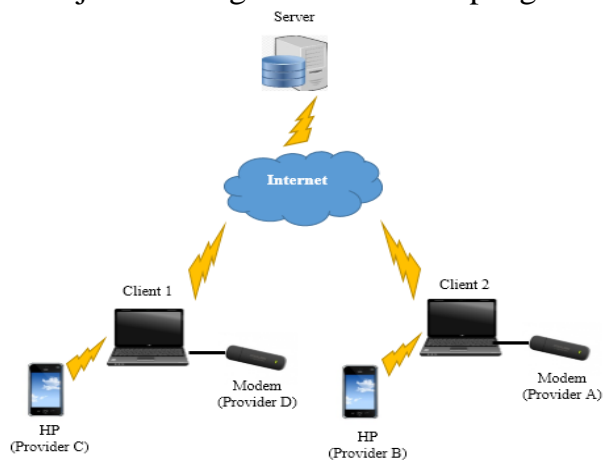

Gambar 4. Arsitektur Pengukuran Delay

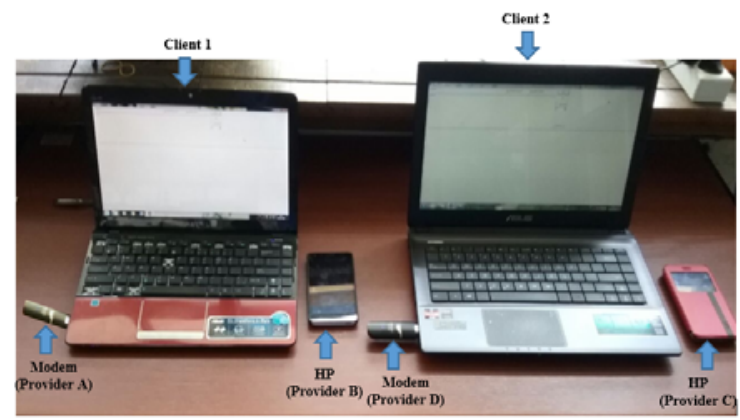

Gambar 5. Konfigurasi alat untuk pengukuran delay

\section{Penentuan Rute}

Pengukuran dilakukan di kereta api komuter jurusan Sidoarjo - Surabaya dan sebaliknya. Kereta api komuter berangkat dari stasiun Porong (Sidoarjo) dan pemberhentian akhir di Stasiun Surabaya Kota (Surabaya). Untuk pengukuran ini titik start dari stasiun Gedangan (Sidoarjo) dan titik finish di stasiun Surabaya Kota (Surabaya). Terdapat 4 shift (keberangkatan kereta) setiap harinya, ditunjukkan oleh Tabel 2.

Tabel 2. Jadwal Kereta Api Komuter

\begin{tabular}{ccccc}
\hline \hline $\begin{array}{c}\text { Shift } \\
\text { ke- }\end{array}$ & $\begin{array}{c}\text { Tempat } \\
\text { Keberangkatan }\end{array}$ & $\begin{array}{c}\text { Jam } \\
\text { Berangka } \\
\text { t }\end{array}$ & $\begin{array}{c}\text { Jam } \\
\text { Tiba }\end{array}$ & $\begin{array}{c}\text { Tempat } \\
\text { Tujuan }\end{array}$ \\
\hline 1 & Stasiun Gedangan & 06.16 & 07.0 & $\begin{array}{c}\text { Stasiun Surabaya } \\
\text { Kota }\end{array}$ \\
2 & Stasiun Surabaya & 13.15 & 14.1 & $\begin{array}{c}\text { Stasiun Gedangan } \\
\text { Kota }\end{array}$ \\
3 & Stasiun Gedangan & 16.28 & 17.2 & $\begin{array}{c}\text { Stasiun Surabaya } \\
\text { Kota }\end{array}$ \\
4 & Stasiun Surabaya & 17.50 & 19.1 & Stasiun Gedangan \\
\hline \hline
\end{tabular}

Stasiun yang dilewati kereta api komuter yaitu sebagai berikut: Stasiun Gedangan, Sawotratap, Stasiun Waru, Kertomenanggal, Jemursari, Stasiun Wonokromo, Stasiun 
Ngagel, Stasiun Gubeng dan Stasiun Surabaya Kota. Dapat dilihat pada Gambar 7.

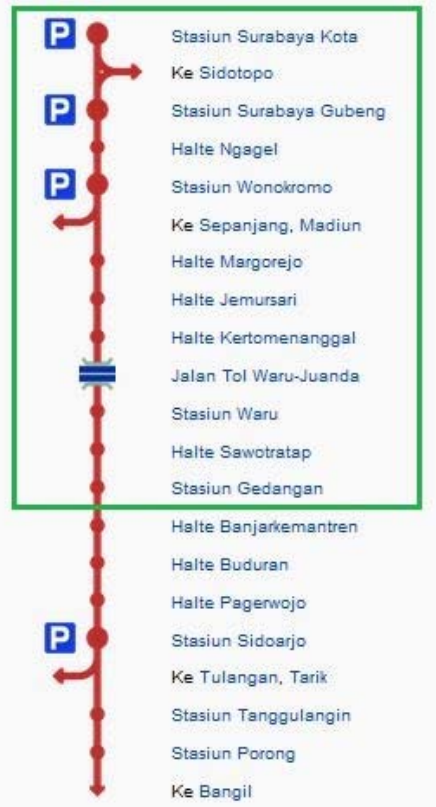

Gambar 6. Rute kereta api Komuter

\section{E. Alur Pengukuran Delay}

Pengukuran kinerja TCP/IP pada jaringan nirkabel bergerak 3G dilakukan di kendaraan bergerak, yaitu kereta api Komuter. Pertama dilakukan persiapan alat yang dibutuhkan. Kemudian menghubungkan mobile phone dan modem ke laptop, menjalankan aplikasi pengukuran. Tidak lupa mengaktikan GPSLogger selama pengukuran, agar dapat mengetahui di titik mana terjadi delay. Proses mengirim data ke server dilakukan setiap 15 detik sekali. Sehingga setiap menitnya terdapat 3 sampai 4 sampel data. Pengukuran dilakukan pada 4 provider. Pengukuran dilakukan selama tujuh hari dengan empat kali shift per harinya. Shift ke-1 merupakan jadwal keberangkatan kereta pagi hari, shift ke-2 pada siang hari, shift ke-3 sore hari dan malam hari pada shift ke-4.

\section{F. Flowchart Aplikasi}

Pada Gambar 8. Merupakan alur aplikasi pengukuran delay.

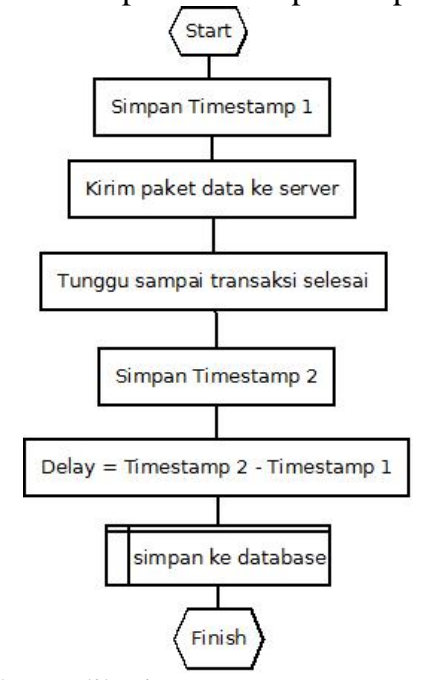

Algoritma yang digunakan pada software PNetDlyTestV2016 yaitu :

a. Mencatat time-stamp komputer sebagai $\mathrm{T}_{\text {awal }}$

b. Mengirim paket data ke server dengan mempergunakan protokol yang telah ditetapkan

c. Menunggu sampai transaksi dengan server selesai dilakukan

d. Mencatat time-stamp komputer sebagai $\mathrm{T}_{\text {selesai }}$

e. Menghitung selesih waktu antara $\mathrm{T}_{\text {selesai }}$ dengan $\mathrm{T}_{\text {awal }}$

f. Menyimpan hasil yang telah didapat ke dalam database

g. Menunggu selama beberapa detik

h. Selanjutnya mengulangi lagi langkah pada poin a.

\section{ANALISIS DAN PEMBAHASAN}

\section{A. Analisis perbandingan pengukuran delay per shift}

Selama tujuh hari pengukuran delay di dalam kereta api Komuter, di mana setiap harinya melakukan pengukuran sebanyak 4 shift pada provider A, B, C dan D ditunjukkan pada Gambar 16.

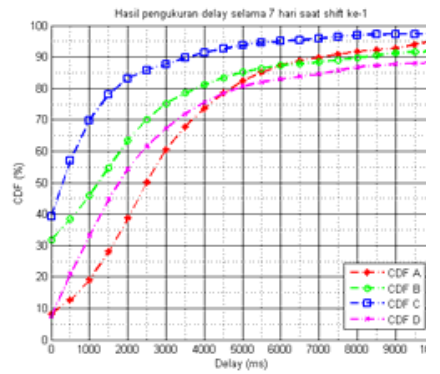

(a)

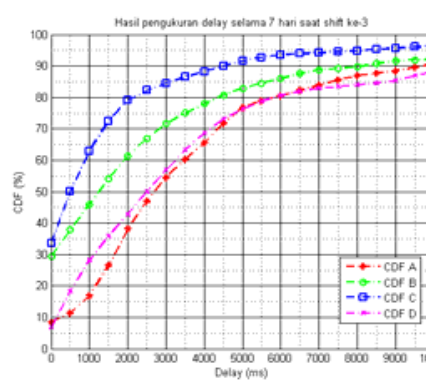

(c)

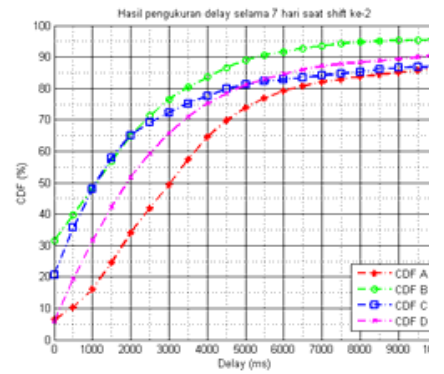

(b)

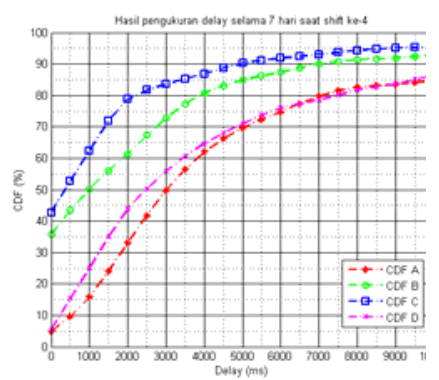

(d)
Gambar 8. Pengukuran delay selama 7 hari shift ke-1 (a), shift ke-2 (b), shift ke-3 (c), shift ke-4 (d)

Dari hasil pengukuran delay yang ditampilkan pada grafik CDF Gambar 16, nilai CDF dapat dikelompokkan menurut delay yang ditentukan pada Tabel 3 .

\begin{tabular}{lrrrrr}
\multicolumn{6}{c}{ Tabel 3. Perbandingan delay setiap shift selama 7 hari } \\
\hline \hline $\begin{array}{l}\text { Delay } \\
\text { (ms) }\end{array}$ & Shift ke- & \multicolumn{2}{c}{ Nilai CDF untuk Provider } \\
& & A (\%) & B (\%) & C (\%) & D (\%) \\
\hline \multirow{3}{*}{500} & 1 & 12 & 39 & 58 & 21 \\
& 2 & 10 & 40 & 37 & 20 \\
& 3 & 11 & 38 & 50 & 18 \\
& 4 & 10 & 44 & 54 & 15 \\
& 1 & 82 & 85 & 94 & 80 \\
& 2 & 74 & 90 & 81 & 81 \\
& 3 & 76 & 83 & 92 & 73 \\
& 4 & 70 & 85 & 91 & 71 \\
\hline \hline
\end{tabular}

Gambar 7. Flowchart aplikasi 
Pada Tabel 3 didapatkan bahwa saat delay sebesar 500 ms, pada shift pertama nilai CDF tertinggi dari provider $\mathrm{C}$ yaitu 58\%. Begitu pula pada saat delay kurang dari 5000 ms nilai CDF 94\% berasal dari provider C. Provider C masih mendominasi dengan nilai CDF lebih tinggi dibandingkan dengan provider lain, meskipun saat jam sibuk yaitu shift ke-1 (pagi hari) dan shift ke-4 (malam hari) di mana didominasi oleh pegawai berangkat dan pulang kerja.

\section{B. Analisis perbandingan pengukuran delay per hari}

Untuk hasil pengukuran mulai dari hari Senin, Selasa, Rabu, Kamis, Jumat, Sabtu dan Minggu, didapatkan perbandingan pengukuran delay setiap harinya pada Gambar 17.

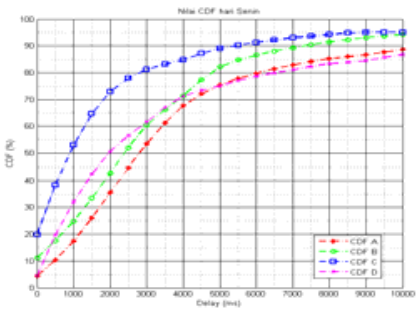

(a)

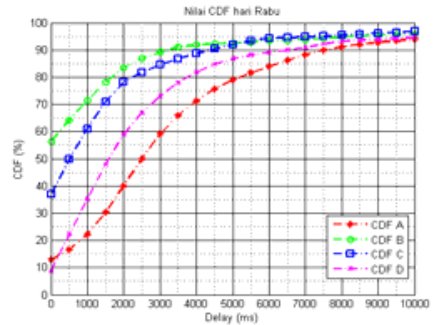

(c)

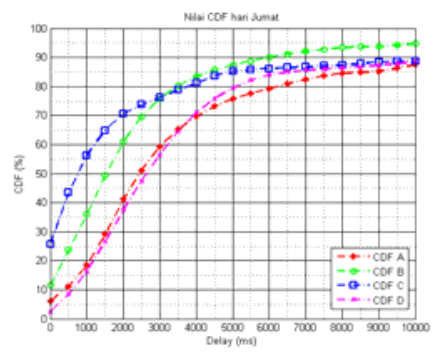

(e)

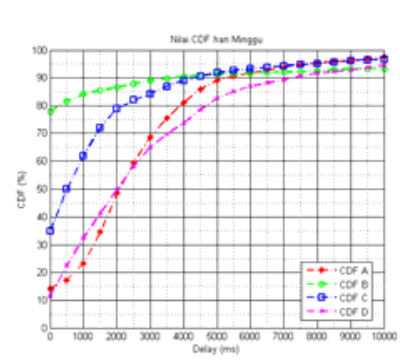

(g)

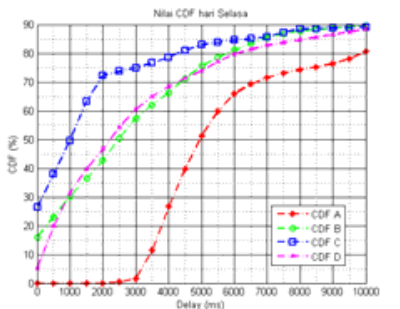

(b)

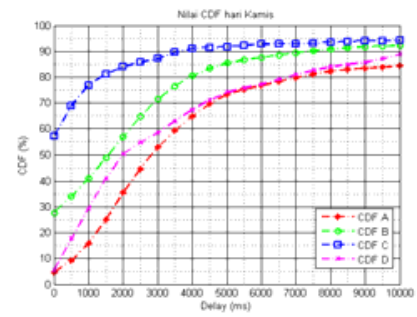

(d)

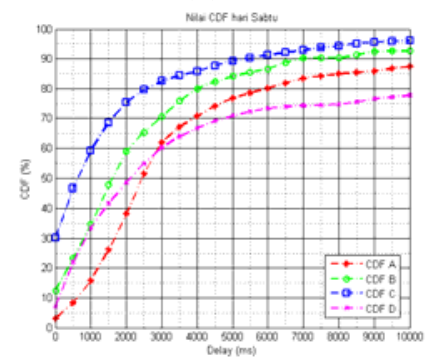

(f)
Gambar 9. Pengukuran delay per hari (a) Senin (b) Selasa (c) Rabu (d) Kamis (e) Jumat (f) Sabtu (g) Minggu

Dari hasil pengukuran delay per hari yang ditampilkan pada grafik CDF Gambar 17, nilai CDF dapat dikelompokkan menurut delay yang ditentukan pada Tabel 4 .
Tabel 4. Perbandingan delay per hari

\begin{tabular}{clrrrrr}
\hline \hline $\begin{array}{l}\text { Delay } \\
(\mathrm{ms})\end{array}$ & Hari & \multicolumn{5}{c}{ Nilai CDF untuk Provider } \\
A (\%) & B (\%) & C (\%) & D (\%) & \\
\hline 500 & Senin & 10 & 17 & 39 & 20 \\
& Selasa & 0 & 21 & 39 & 20 \\
& Rabu & 16 & 64 & 50 & 21 \\
& Kamis & 10 & 35 & 70 & 17 \\
& Jumat & 9 & 24 & 43 & 11 \\
& Sabtu & 9 & 24 & 47 & 22 \\
& Minggu & 17 & 82 & 50 & 23 \\
5000 & Senin & 75 & 83 & 90 & 75 \\
& Selasa & 51 & 76 & 84 & 75 \\
& Rabu & 80 & 92 & 92 & 90 \\
& Kamis & 74 & 86 & 92 & 74 \\
& Jumat & 75 & 88 & 87 & 80 \\
& Sabtu & 76 & 85 & 90 & 70 \\
& Minggu & 90 & 92 & 92 & 83 \\
\hline \hline
\end{tabular}

Pada Tabel 4.10 didapatkan bahwa selama pengukuran delay seminggu, saat delay kurang dari $500 \mathrm{~ms}$ sebagian besar nilai CDF pada masing-masing provider belum mencapai 50\% $\mathrm{CDF}$, kecuali pada hari libur (Minggu). Pada hari minggu nilai CDF bisa mencapai $82 \%$ untuk provider B. Saat delay kurang dari $5000 \mathrm{~ms}$, hampir semua provider akan mencapai $100 \%$ $\mathrm{CDF}$, kecuali pada hari selasa provider A masih mencapai $50 \% \mathrm{CDF}$.

\section{Analisis pengukuran delay selama 7 hari per provider}

Dari tujuh hari pengukuran jumlah data yang diperoleh 13.214 data. Provider yang diteliti sejumlah 4, yaitu provider A, povider B, provider C dan provider D. Provider A ditunjukkan dengan garis berwarna merah, graris berwarna hijau untuk povider $\mathrm{B}$, sedangkan provider $\mathrm{C}$ ditunjukkan dengan garis berwarna biru dan provider D ditampilkan dengan garis berwarna merah muda.

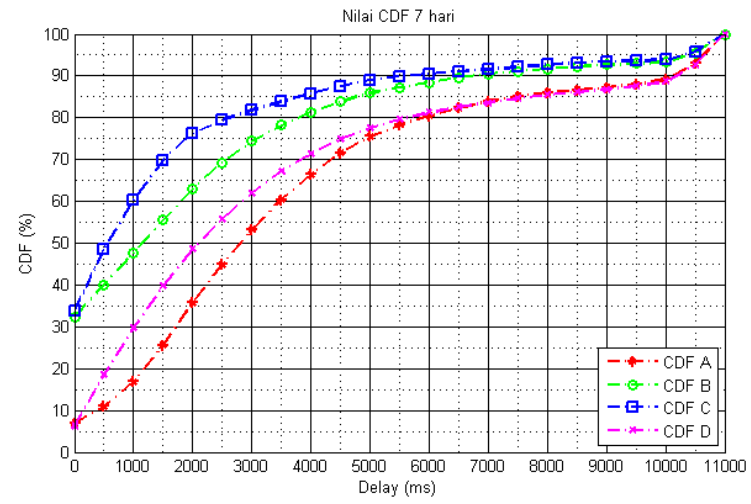

Gambar 10. Grafik CDF selama 7 hari untuk 4 provider

Dari Gambar 18 disajikan data berupa tabel, agar memudahkan dalam membaca dan membandingkan hasil pengukuran. Hasilnya terdapat pada Tabel 5

\begin{tabular}{lrlllll}
\multicolumn{6}{l}{ Tabel 5 Perbandingan pengukuran delay setiap provider selama 7 hari } \\
\hline \hline $\begin{array}{l}\text { Delay } \\
\text { (ms) }\end{array}$ & \multicolumn{7}{l}{ Nilai CDF untuk Provider } & & & \\
& A (\%) & B (\%) & C (\%) & D (\%) & \\
\hline 500 & 10 & 40 & 49 & 19 \\
5000 & 75 & 81 & 90 & 77 \\
\hline
\end{tabular}

Acuan delay yang digunakan pada tugas akhir ini merupakan standar dari SLAC (Stanford Linear Accelerator Center). SLAC adalah pusat penelitian Universitas Stanford yang dilakukan oleh Departemen Penelitian Energi Nasional. Penelitiannya berkaitan dengan telekomunikasi, salah satunya 
tentang kualitas kinerja jaringan (QoS), dalam hal ini delay, dapat dilihat pada Tabel 1.

Faktor yang menyebabkan delay pada jaringan nirkabel bergerak yaitu : jaringan dengan trafik yang tinggi, mobilitas, banyaknya pengguna jaringan dan waktu pengukuran.

Pemilihan delay sebesar 500 dan 5000 ms dikarenakan untuk penerapan Intelligent Transport System pada aplikasi mengetahui posisi kendaraan dibutuhkan delay toleransi sebesar 500 ms untuk V2V [21]. V2V (Vehicle to Vehicle) ini di mana antara kendaraan saling komunikasi mengirimkan pesan misalnya pengereman apabila jarak antar 2 kendaraan terlalu dekat saat kecepatan tinggi. Dari Tabel 5 didapatkan bahwa untuk penerapan aplikasi mengetahui posisi kendaraan dengan delay toleransi 500 ms menggunakan provider A, B, C dan D kurang sesuai, karena nilai CDF semua provider belum mencapai 50\%.

Sedangkan delay toleransi sebesar 5000 ms digunakan untuk mengetahui posisi kendaraan untuk V2i (Vehicle to Infrastructure) [6]. Dalam hal ini angkutan cepat masal, di mana data posisi berupa titik longitude dan titik latitude dikirim dari OBU ke server. Dari Tabel 5 didapatkan bahwa untuk penerapan aplikasi mengetahui posisi kendaraan dengan delay toleransi 5000 ms menggunakan provider A, B, C dan D masih sesuai, karena sebagian besar nilai CDF tinggi. Saat delay kurang dari $5000 \mathrm{~ms}$ provider A mempunyai nilai $\mathrm{CDF} 75 \%$, provider $\mathrm{B}$ dengan nilai $\mathrm{CDF}$ $81 \%$, provider C dengan nilai CDF yaitu $90 \%$ dan yang terakhir provider D dengan nilai CDF 77\%. Dari keempat provider, provider $\mathrm{C}$ yang paling mempunyai nilai CDF paling tinggi sebesar $90 \%$ artinya $90 \%$ dari data pengukuran keseluruhan mempunyai delay kurang dari $5000 \mathrm{~ms}$. Menurut standar SLAC nilai delay 5000 ms dapat dikategorikan sebagai sedang - hampir semua terlayani (Sporadically interactive regime).

\section{KESIMPULAN/RINGKASAN}

\section{A. Kesimpulan}

Dari hasil pengukuran dan analisis dapat disimpulkan sebagai berikut :

a. Pengukuran dilakukan untuk mengetahui besar delay pada 4 provider seluler pada jaringan 3G di kereta api Komuter Surabaya.

b. Pada 4 provider yang diukur didapat bahwa saat delay kurang dari 5000 ms provider A mempunyai nilai CDF $75 \%$, provider B dengan nilai CDF $81 \%$, provider C dengan nilai CDF yaitu $90 \%$ dan yang terakhir provider D dengan nilai CDF 77\%. Dari keempat provider, provider C mempunyai nilai CDF paling tinggi sebesar $90 \%$.

c. Provider $\mathrm{C}$ dapat digunakan sebagai pertimbangan sistem komunikasi data pada penerapan Intelligent Transport System (ITS) untuk aplikasi mengetahui posisi kendaraan pada angkutan masal cepat, karena nilai delay toleransi sebesar 5 detik dan dapat dikategorikan sedang dan hampir semua terlayani.

\section{B. Saran}

Adapun hal yang masih bisa dikembangkan dari tugas akhir ini adalah dalam pengembangan ke depan bisa dilakukan pengukuran terhadap jitter, throughput dan loss.

\section{DAFTAR PUSTAKA}

[1] Stallings, William, "Komunikasi Data dan Jaringan Komputer", Erlangga, Jakarta, 2007.

[2] Yuniati, Yetti, "Analisis Performansi Transmission Control Protocol (TCP) yang Disebabkan oleh Wideband Effect Loss pada Jaringan UMTS”, Jurnal Rekayasa dan Teknologi Elektro, Vol. 5, No. 3, pp. 159-166, September, 2011.

[3] Team, Deloitte Global Mobile Consumer Survey. https://www2.deloitte.com/content/dam/Deloitte/global/Documents/Tec hnology-Media-Telecommunications/gx-tmt-2015-global-mobileconsumer-survey-southeast-asia-edition.pdf, 2015.

[4] Pratama, I Putu Eka, Smart City beserta Cloud Computing dan Teknologi-Teknologi Pendukung Lainnya, Informatika, Bandung, 2014.

[5] _ Pra Studi Kelayakan AUMC Pemkot Sby, 2012, Pemkot Surabaya

[6] Idris, Izwan, Wang, Charles, Real-time position tracking via Internet communication protocols in LBS, International Global Navigation Satellite Systems Society, Australia, 2015

[7] Stallings, William, "Komunikasi Data dan Komputer Dasar-Dasar Komunikasi Data”, Salemba Teknika, Jakarta, 2001.

[8] Stallings, William, Komunikasi Data dan Komputer Edisi 1, Salemba Teknika, Jakarta, 2001.

[9] Stallings, William, Komunikasi dan Jaringan Nirkabel Edisi 2, Erlangga, Jakarta, 2005.

[10] Santoso, Gatot, Sistem Seluler WCDMA(Wideband Code Division Multiple), Yogyakarta : Graha Ilmu, 2006.

[11] $\longrightarrow$ Internetworking Technology Handbook, <URL:http://docwiki.cisco.com/wiki/Internetworking_Technology_Ha ndbook $>$

[12] _Tutorial internet monitoring \& PingER at SLAC. http://www.slac.stanford.edu/comp/net/wan-mon/tutorial.html\#delay ,2014.

[13] Harinaldi, "Prinsip-Prinsip Statistik untuk Teknik dan Sains”, Jakarta, 2005.

[14] $\longrightarrow$ Kereta Api Delta Ekspress, <URL : https://id.wikipedia.org/wiki/Kereta_api_Delta_Ekspres>

[15] Adipranata, Rudy, "Implementasi Protokol TCP/IP Untuk Pengendalian Komputer Jarak Jauh”, Jurnal Informatika, Vol. 3, No. 1, pp. 34-41, Mei, 2004.

[16] Catalan, M, TCP/IP Analysis And Optimization Over A Precommercial Live UMTS Network, IEEE, 2005

[17] Hu, Zhenxian, Chen, Yi-Chao, Qiu, Lili, An In-Depth Analysis of $3 G$ Traffic and Performance, ACM, 2015

[18] Jang, Keon, 3G and 3.5G Wireless Network Performance Measured Moving Cars and High-Speed Trains, ACM MICNET, 2009.

[19] Jiang, Haiqing, Trakling Bufferbloat in 3G / 4G Mobile Networks, NCSU, 2012.

[20] Osama, Ahmed, 3G Network Architecture Model, <URL:http://electrical-engineering-world1.blogspot.co.id/2015/03/3gnetwork-architecture-model.html $>$

[21]Papadimitratos, Panos, Vehicular Communication Systems: Enabling Technologies, Applications, and Future Outlook on Intelligent Transportation, IEEE, 2009. 